\title{
KINERJA PRODUKSI PENDEDERAN JUVENIL LOBSTER PASIR Panulirus homarus MENGGUNAKAN SELTER INDIVIDU
}

\author{
Kukuh Adiyana\# dan Amin Pamungkas \\ Pusat Riset Perikanan \\ (Naskah diterima: 7 Juni 2017; Revisi final: 25 September 2017; Disetujui publikasi: 25 September 2017)
}

\begin{abstract}
ABSTRAK
Kanibalisme yang tinggi adalah salah satu permasalahan utama dalam budidaya lobster. Penggunaan selter individu pada budidaya pendederan lobster dimaksudkan untuk meniadakan kontak langsung antar lobster dalam media budidaya. Tujuan penelitian ini adalah untuk menganalisis kualitas air dan pengaruh penggunaan selter individu terhadap kinerja produksi pendederan lobster pasir Panulirus homarus dengan sistem resirkulasi. Lobster berukuran 51,29 \pm 7,26 g/ekor dipelihara selama 60 hari dengan pemberian pakan 3\%4\%sebanyak satu kali per hari. Penelitian dilakukan dengan empat perlakuan dan dua ulangan. Jenis perlakuan yang digunakan, yaitu selter pipa PVC sebagai kontrol (K), selter individu persegi (SI $\mathbf{\bullet}$ ), selter individu segitiga (S| $\mathbf{\Lambda}$ ), dan selter individu tabung (SI $\bullet$ ). Hasil penelitian menunjukkan bahwa kualitas air budidaya menggunakan sistem resirkulasi masih memenuhi syarat untuk budidaya lobster. Penggunaan selter individu berpengaruh positif terhadap respons sintasan, tetapi berpengaruh negatif terhadap pertumbuhan lobster.
\end{abstract}

\section{KATA KUNCl: sintasan; lobster pasir; pertumbuhan; selter individu}

ABSTRACT: Water quality and production response during spiny lobster (Panulirus homarus) juvenile rearing using individual shelter on recirculating aquaculture system. By: Kukuh Adiyana dan Amin Pamungkas

\begin{abstract}
High cannibalism was an important issue in lobster rearing. The use of individual shelter in lobster rearing was intended to eliminate a direct contact between lobsters in a rearing media. The purpose of this study was to analyzewater quality and the effect of individual shelter on the growth response of spiny lobster (Panulirus homarus) juvenile reared in an aquaculturemedia equipped with a recirculation system. Lobsters with an average size of $51.29 \pm 7.26 \mathrm{~g}$ were reared for 60 days and fed with trash fish of 3\%4\% of the biomass daily. This study used four treatments with two replications. The treatments consisted of a PVC pipe shelter as control (K), individual square shelter (SI $\boldsymbol{m})$, individual triangle shelter(SI $\mathbf{\Lambda}$ ), and individual tube shelter (S| ๑).Theresults of the study showed that the water quality in the aquaculture media was still within the suitable range for lobster rearing. The use of individual shelter had positive effects on the survival rate but had negative effects on the growth of spiny lobster juvenile.
\end{abstract}

KEYWORDS: survival rate; spiny lobster; growth; individual shelter

\section{PENDAHULUAN}

Lobster pasir Panulirus homarus merupakan komoditas perikanan bernilai ekonomis tinggi. Permintaan konsumsi lobster air laut terus meningkat dari tahun ke tahun. Menurut Drengstig \& Bergheim (2013), permintaan kebutuhan lobster air laut di pasar internasional mencapai 2.000-2.500 ton/tahun. Sementara itu, pasokan lobster di pasar tidak tersedia secara kontinu. Upaya budidaya lobster telah banyak

\# Korespondensi: Pusat Riset Perikanan. Gedung Balitbang KP 2, Jl. Pasir Putih 2, Ancol Timur, Jakarta Utara, Indonesia.

Tel.: + 622164700928

E-mail: k_adiyana@yahoo.com dilakukan sebagai upaya memenuhi kebutuhan permintaan lobster.

Salah satu kendala dalam kegiatan budidaya pembesaran lobster adalah rendahnya sintasan benih yang dibudidayakan (Thuy \& Ngoc, 2004). Tingkat sintasan pembesaran lobster di wilayah Lombok dan Sukabumi hanya berkisar 30\%50\% (Lesmana, 2013). Mortalitas yang tinggi dalam budidaya lobster, umumnya disebabkan oleh kanibalisme. Upaya pencegahan kanibalisme dalam sistem budidaya lobster, dapat dilakukan dengan penyediaan tempat persembunyian buatan (selter) (Musbir et al., 2014). 
Aplikasi selter konvensional yang biasa digunakan para pembudidaya lobster seperti rumput laut, karung plastik (teknik pocong), potongan bambu (Suastika et al., 2008), batu karang, kayu, atau jaring (Nguyen et al., 2009), masih belum optimal dalam meningkatkan sintasan lobster. Penggunaan selter hanya dapat meminimalkan kontak antar benih lobster, namun diduga masih kurang efektif untuk mengatasi kanibalisme. Menurut Irvin \& Williams (2009), pemeliharaan lobster secara individu menghasilkan sintasan yang lebih baik apabila dibandingkan dengan pemeliharaan sistem komunal.

Menurut Drengstig \& Bergheim (2013), aplikasi teknologi Recirculating Aquaculture System (RAS)/sistem akuakultur dengan resirkulasi pada kegiatan pendederan lobster, dapat digunakan untuk menjaga kualitas air dan meminimumkan risiko terjadinya serangan penyakit. Proses pendederan lobster ini bertujuan untuk memberi kesempatan bagi benih lobster untuk beradaptasi dengan lingkungan yang baru, sehingga benih yang dihasilkan bersifat lebih adaptif terhadap perubahan kondisi lingkungan, dan dapat mengurangi tingkat kematian benih (Syda-Rao et al., 2010; M ohammed et al., 2010). Penelitian ini bertujuan untuk menganalisis kualitas air dan pengaruh penggunaan selter individu yang berbeda terhadap kinerja produksi juvenil lobster pasir (Panulirus homarus).

\section{BAHAN DAN METODE}

\section{Benih Lobster}

Benih lobster yang digunakan dalam penelitian adalah lobster pasir Panulirus homarus dengan bobot rata-rata 50,07 $\pm 2,89 \mathrm{~g} / \mathrm{ekor}$. Padat tebar pada setiap perlakuan adalah sebesar $35 \mathrm{ekor} / \mathrm{m}^{2}$. Benih lobster dipelihara di dalam bak perlakuan selama 60 hari.

\section{Pakan}

Pemberian pakan pada penelitian ini digunakan pakan segar, yaitu potongan ikan rucah yang diperoleh dari nelayan sekitar kawasan Ancol. Pakan diberikan satu kali pada sore hari pukul 17.00 WIB. Feeding rate yang digunakan dalam penelitian ini adalah 3\%4\%bobot lobster.

\section{Selter Individu}

Selter individu (SI) yang digunakan dalam penelitian ini terdiri atas berbagai bentuk yaitu SI tabung modifikasi dari pipa PVC, SI segitiga modifikasi dari talang air PVC, dan SI persegi modifikasi dari keranjang plastik komersil. Bentuk dan ukuran SI yang digunakan dapat dilihat pada Gambar 1.

\section{Sistem Resirkulasi yang Digunakan dalam Penelitian}

Pemeliharaan lobster dilakukan secara indoor dengan menggunakan delapan buah bak plastik untuk perlakuan, satu bak plastik untuk tampungan filtrat, dan satu bak fiber untuk tampungan outlet bak perlakuan dan protein skimmer. Bak plastik yang digunakan berdimensi $1,2 \mathrm{~m} \times 0,95 \mathrm{~m} \times 1 \mathrm{~m}$; sedangkan bak fiber berbentuk lingkaran dengan diameter $1,5 \mathrm{~m}$ dan tinggi $0,75 \mathrm{~m}$. Pada penelitian ini, digunakan sistem resirkulasi, dengan mengoperasikan tiga pompa submersible kapasitas 12.000 L/jam masing-masing untuk sistem filtrasi, skimmer, dan distribusi.

\section{Rancangan Penelitian}

Pada Penelitian ini digunakan rancangan acak lengkap, terdiri atas empat perlakuan dan dua ulangan. Perlakuan yang digunakan adalah pemeliharaan lobster dengan aplikasi berbagai bentuk selter individu (SI) yaitu SI tabung, SI segitiga, SI persegi, dan selter pipa PVC sebagai kontrol.

Pengukuran parameter suhu, salinitas, $\mathrm{pH}$, oksigen terlarut (dissolved oxygen/DO), dan alkalinitas dilakukan setiap hari secara in-situ. Analisis laboratorium kualitas air dilakukan pada hari ke-0, 10, 20, 30, 40, 50, dan 60 , meliputi parameter amonia, nitrit, nitrat, dan total organic matter (TOM). Analisis kualitas air mengacu pada metode Clesceri et al. (1999).

Pengamatan biometri lobster dilakukan secara insitu pada hari ke-0, 10, 20, 30, 40, 50, 60, meliputi sampling bobot dan panjang karapaks lobster. Pengukuran biometri mengacu pada Solanki et al. (2012). Frekuensi moulting dihitung dengan cara pengamatan langsung pada lobster di setiap perlakuan. Karapaks lobster yang tanggal pada perlakuan SI tabung, SI segitiga, dan SI persegi dicatat per setiap unit SI, sehingga dapat diketahui frekuensi moulting per individu lobster. Pada perlakuan kontrol pemeliharaan bersifat komunal, sehingga dicatat jumlah total moulting secara menyeluruh mewakili jumlah lobster dalam perlakuan tersebut. Tingkat sintasan (SR) diamati pada akhir penelitian.

Data sintasan (SR), laju pertumbuhan harian (SGR), rasio konversi pakan (FCR), dan frekuensi moulting dianalisis secara statistik menggunakan analisis ragam (ANOVA) dengan software statistik Minitab 16. Pada ANOVA dilakukan uji F pada selang kepercayaan $95 \%$ untuk menentukan ada atau tidaknya pengaruh perlakuan terhadap parameter uji. Apabila berpengaruh nyata maka dilakukan uji lanjut dengan metode Tukey. Data kualitas air dianalisis secara deskriptif. Beberapa persamaan rumus yang digunakan adalah: 
(a)

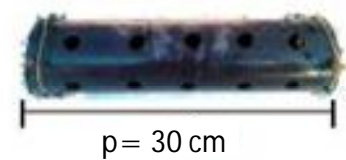

(b)

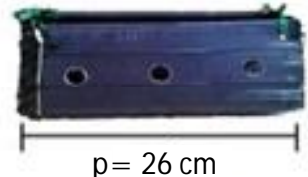

(c)

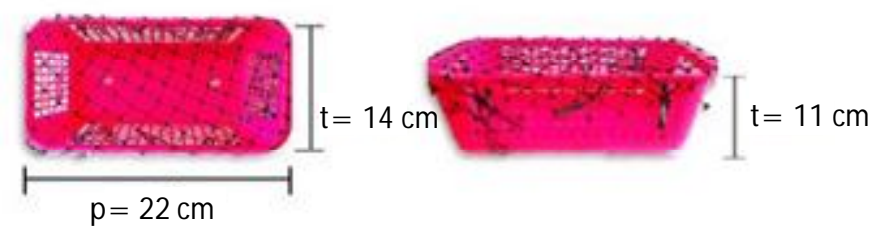

Gambar1. Dimensi berbagai bentuk selter individu (SI): (a) SI tabung, (b) SI segitiga, dan (c) SI persegi.

Figure 1. Types and dimensions of individual shelters used in this study: (a) SI tube, (b) SI triangle, and (c) SI square.

\section{Sintasan}

Sintasan atau survival rate (SR), dihitung dengan rumus (Solanki et al., 2012):

$$
\mathrm{SR}=\frac{\mathrm{Nt}}{\mathrm{No}} \times 100 \%
$$

di mana:

$\mathrm{SR}=\operatorname{sintasan}(\%$

$\mathrm{Nt}=$ jumlah lobster hidup pada akhir penelitian (ekor)

No = jumlah lobster hidup pada awal penelitian (ekor)

\section{Laju Pertumbuhan Spesifik}

Laju pertumbuhan spesifik atau specific growth rate (SGR) dihitung dengan menggunakan rumus (Solanki et al., 2012):

di mana:

$$
\text { SGR }\left(\%=\mid\left(W t / W_{0}\right)^{1 / t}-1\right] \times 100 \%
$$

SGR = laju pertumbuhan spesifik $(\%)$

$\mathrm{Wt}=$ bobot rata-rata lobster pada akhir penelitian $(\mathrm{g})$

Wo $=$ bobot rata-rata lobster pada awal penelitian $(\mathrm{g})$

$\mathrm{T}=$ periode penelitian (hari)

\section{Rasio Konversi Pakan}

Rasio konversi pakan atau feed convertion ratio (FCR) dihitung dengan menggunakan rumus (Zonneveld et al., 1991):

di mana:

$$
F C R=\frac{F}{B t+B m-B o}
$$

$\mathrm{FCR}=$ rasio konversi pakan

$\mathrm{F}=$ jumlah pakan

Bt = biomassalobster akhir penelitian (g)

$\mathrm{Bm}=$ biomassa lobster yang mati selama penelitian $(\mathrm{g})$

$\mathrm{Bo}=$ biomassa lobster awal penelitian $(\mathrm{g})$

\section{Panjang Total}

Panjang total dihitung dengan menggunakan persamaan (Solanki et al., 2012):

$$
\begin{aligned}
\text { Panjang total }= & \text { panjang karapaks }+ \text { panjang } \\
& \text { abdominal }
\end{aligned}
$$

\section{HASIL DAN BAHASAN}

\section{Kualitas Air}

Kondisi kualitas air selama kegiatan budidaya dapat dilihat pada Tabel 1.

Secara keseluruhan kondisi kualitas air selama penelitian masih memenuhi standar untuk budidaya lobster (Tabel 1). Penggunaan sistem resirkulasi dengan filter dan protein skimmer terbukti dapat menjaga kualitas air pada kondisi optimal selama budidaya pendederan lobster.

\section{Kinerja Produksi}

\section{Respons Pertumbuhan}

Bobot dan panjang karapaks lobster pada semua perlakuan meningkat seiring dengan lamanya waktu penelitian (Gambar 2 dan 3). Bobot lobster tertinggi pada akhir penelitian, terdapat pada kontrol yaitu sebesar 73,74 $\pm 2,15 \mathrm{~g}$ dengan panjang karapaks sebesar 53,56 $\pm 2,52 \mathrm{~mm}$.

Laju pertumbuhan bobot harian lobster (SGR) tertinggi terdapat pada kontrol, yaitu sebesar 0,65 \pm $0,04 \%$ sedangkan terendah terdapat pada perlakuan SI • sebesar 0,23 $\pm 0,045 \%$ (Gambar 4). Penggunaan 
Tabel 1. Kondisi kualitas air selama penelitian

Table 1. The condition of water quality during the study

\begin{tabular}{|c|c|c|c|}
\hline $\begin{array}{l}\text { Parameter } \\
\text { Parameters }\end{array}$ & $\begin{array}{l}\text { Nilai } \\
\text { Value }\end{array}$ & $\begin{array}{l}\text { Standar } \\
\text { Standard }\end{array}$ & $\begin{array}{l}\text { Referensi } \\
\text { References }\end{array}$ \\
\hline $\begin{array}{l}\text { Suhu } \\
\text { Temperature }\left({ }^{\circ} \mathrm{C}\right)\end{array}$ & $27.55 \pm 0.08-29.30 \pm 0.14$ & $25.00-30.00$ & Phillips \& Kittaka (2000) \\
\hline $\begin{array}{l}\text { Salinitas } \\
\text { Salinity (ppt) }\end{array}$ & $33.10 \pm 0.05-34.50 \pm 0.06$ & $32.00-36.00$ & Wickins \& Lee (2002) \\
\hline $\mathrm{pH}$ & $7.90 \pm 0.07-8.30 \pm 0.10$ & $7.80-8.50$ & Wickins \& Lee (2002) \\
\hline $\begin{array}{l}\text { Alkalinitas } \\
\text { Alkalinity (mg/L) }\end{array}$ & $45.12 \pm 0.03-246.88 \pm 0.05$ & $40.00-200.00$ & $\begin{array}{c}\text { Chen et al . (2006); } \\
\text { Biesterfeld et al . (2003) }\end{array}$ \\
\hline $\begin{array}{l}\text { Oksigen terlarut } \\
\text { Dissolved oxygen (mg/L) }\end{array}$ & $4.21 \pm 0.15-7.00 \pm 0.14$ & $2.70-5.40$ & Phillips \& Kittaka (2000) \\
\hline $\begin{array}{l}\text { Amonia }\left(\mathrm{NH}_{3}\right) \\
\text { Ammonia }\left(\mathrm{NH}_{3}\right)(\mathrm{mg} / \mathrm{L})\end{array}$ & $0.00 \pm 0.00-0.06 \pm 0.01$ & $<1.00$ & Wickins \& Lee (2002) \\
\hline $\begin{array}{l}\text { Nitrit } \\
\text { Nitrite }(\mathrm{mg} / \mathrm{L})\end{array}$ & $0.02 \pm 0.01-0.44 \pm 0.05$ & $<5.00$ & Drengstig \& Bergheim (2013) \\
\hline $\begin{array}{l}\text { Nitrat } \\
\text { Nitrate }(\mathrm{mg} / \mathrm{L})\end{array}$ & $0.01 \pm 0.00-6.78 \pm 0.09$ & $<100.00$ & Wickins \& Lee (2002) \\
\hline $\begin{array}{l}\text { Bahan organik total } \\
\text { Total organic matter (mg/L) }\end{array}$ & $29.90 \pm 0.77-115.30 \pm 0.80$ & $14.70-225.10$ & Budiardi et al . (2007) \\
\hline
\end{tabular}

SI - dan perlakuan kontrol menghasilkan Iaju pertumbuhan bobot harian yang berbeda nyata $(P<0,05)$ dengan perlakuan SI $\Delta$ dan SI •. Bobot, panjang karapaks dan laju pertumbuhan bobot harian lobster selama penelitian dapat dilihat pada Gambar 2, 3, dan 4 .
Pertumbuhan adalah perubahan bentuk dan ukuran, baik panjang, bobot atau volume dalam jangka waktu tertentu (Hargiyatno et al., 2013). Pertumbuhan merupakan peningkatan biomassa sebagai proses transformasi materi dari energi pakan menjadi massa tubuh. Pada krustasea, pertumbuhan panjang dan

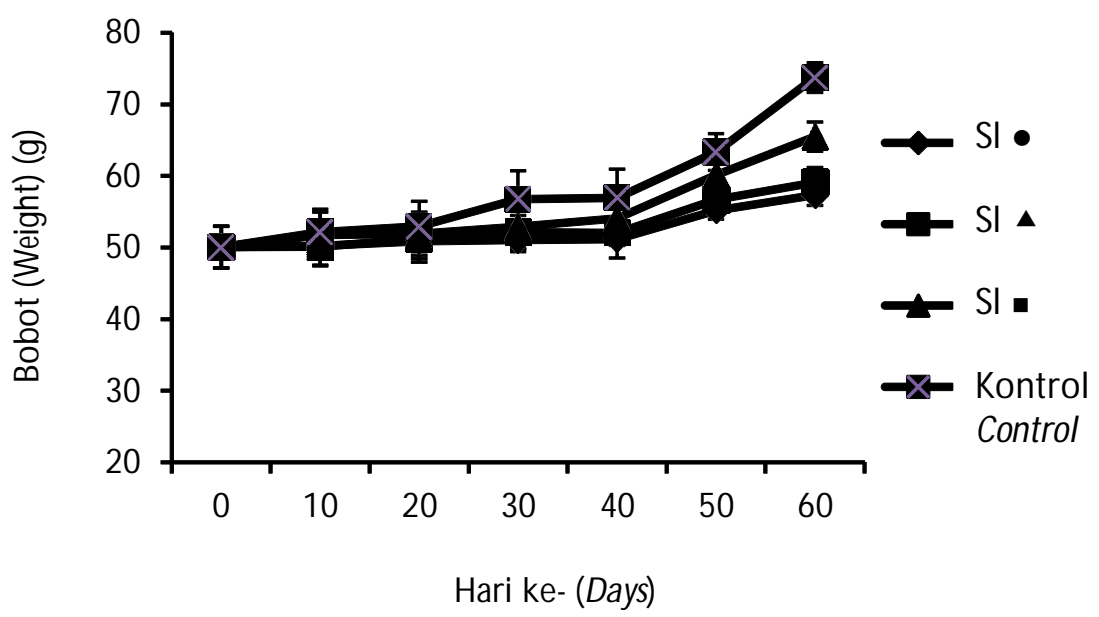

Gambar 2. Bobot rata-rata lobster pada berbagai macam selter individu selama penelitian. (SI •) selter individu tabung, (SI $\mathbf{\Delta})$ selter individu segitiga, (SI -) selter individu persegi.

Figure 2. Mean body weight of lobster in different individual shelter during the study. (SI •) individual tube shelter, (SI $\mathbf{\Delta})$ individual triangle shelter, (SI -) individual square shelter. 


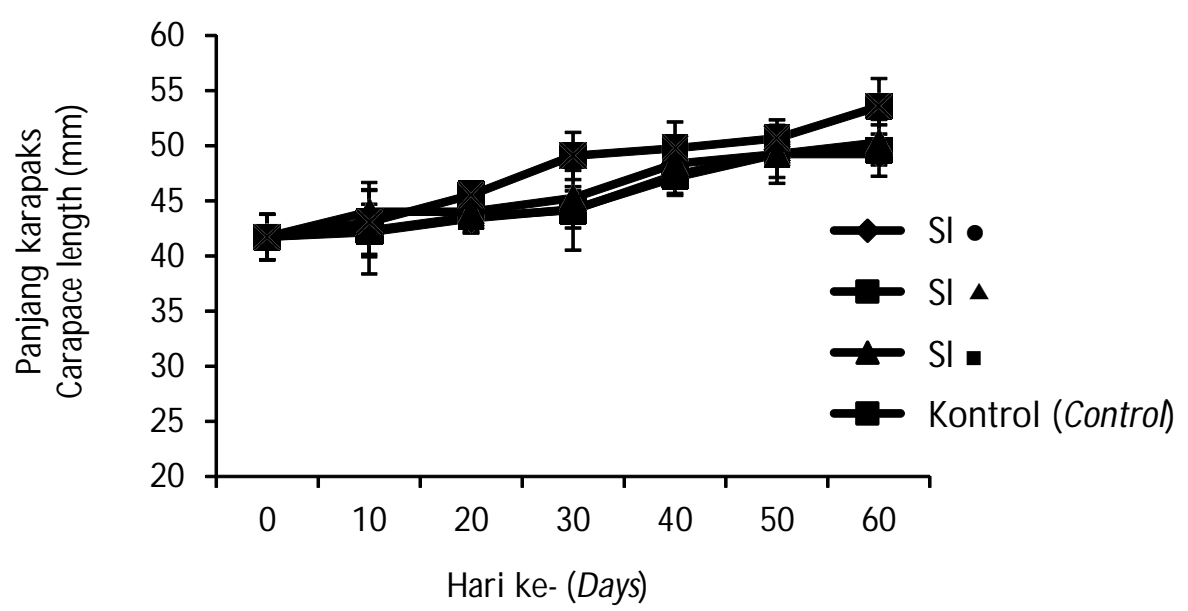

Gambar 3. Panjang karapaks rata-rata lobster pada berbagai macam selter individu selama penelitian. (SI •) selter individu tabung, (SI «) selter individu segitiga, (SI •) selter individu persegi.

Figure 3. Mean length of lobster carapace reared in different various individual selther during the study. (SI •) individual tube shelter, (SI $\mathbf{4})$ individual triangle shelter, (SI -) individual square shelter.

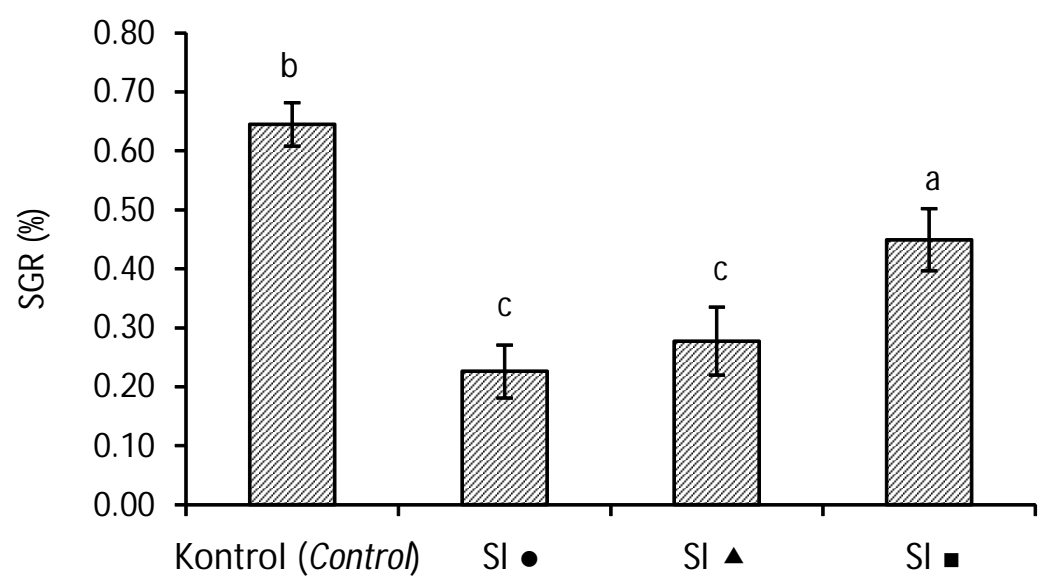

Gambar 4. Laju pertumbuhan bobot harian lobster pada berbagai macam selter individu selama penelitian. Huruf kecil yang berbeda dalam grafik menunjukkan beda nyata $(P<0,05)$.

Figure 4. The specific growth rate of lobster in different individual shelter during the study. Different letters at the top of the bars indicate significantly different $(P<0.05)$.

bobot tubuh terjadi secara berkala setelah moulting (Bianchini \& Ragonese, 2007).

Lobster pada perlakuan kontrol memiliki SGR tertinggi sebesar $0,65 \pm 0,04 \%$ dibanding dengan perlakuan lainnya. Hal ini disebabkan pada perlakuan kontrol terdapat kanibalisme yang lebih besar, sehingga lobster mendapat asupan tambahan selain dari pakan yang diberikan. Hal ini dapat dilihat pada sintasan perlakuan kontrol merupakan yang terendah yaitu sebesar 74,28 \pm 4,04\% Faktor kanibalisme akan mengurangi populasi lobster, sehingga persaingan dalam perebutan pakan akan menurun dan lobster dapat memanfaatkan pakan dengan lebih baik. Menurut Cokrowati et al. (2012), lobster dengan padat tebar rendah akan semakin efisien dalam memanfaatkan pakan yang diberikan.

\section{Rasio Konversi Pakan}

Rasio konversi pakan lobster terendah $(15,48 \pm$ $1,26)$ terdapat pada perlakuan kontrol, sedangkan tertinggi $(28,19 \pm 0,49)$ terdapat pada perlakuan SI •. Rasio konversi pakan lobster selama penelitian dapat dilihat pada Gambar 5. 


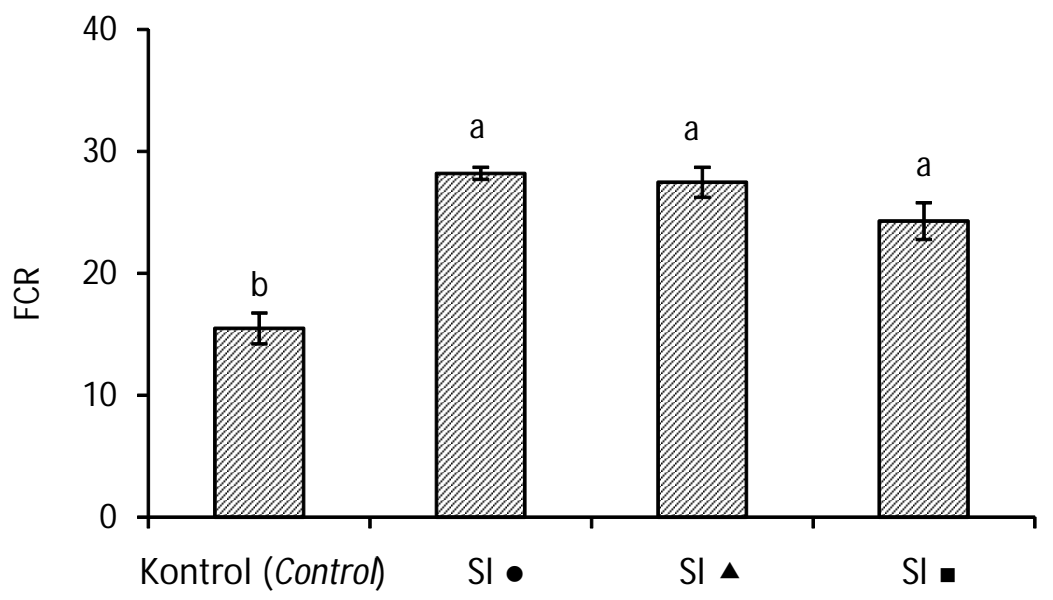

Gambar 5. Rasio konversi pakan lobster pada berbagai macam selter individu. Huruf kecil yang berbeda dalam grafik menunjukkan beda nyata $(P<0,05)$.

Figure 5. The feed conversion ratio of lobster reared in different individual shelter during the study. Different letters at the top of the bars indicate significantly different $(P<0.05)$.

Metabolisme yang berjalan baik akan berpengaruh terhadap nilai efisiensi pakan yang dikonsumsi oleh lobster. Nilai efisiensi pakan menunjukkan persentase pakan yang dimanfaatkan oleh lobster untuk pertumbuhan (diwakili oleh penambahan bobot badan) berbanding dengan jumlah pakan yang dikonsumsi. Masih tingginya rasio konversi pakan ini, disebabkan pakan ikan rucah yang diberikan, memiliki kandungan kadar air yang cukup tinggi yaitu 78,62 $\pm 0,17 \%$ Menurut Phillips \& Kittaka (2000), penggunaan pakan basah pada juvenil lobster menghasilkan rasio konversi pakan 3-9, akan tetapi pada penelitian lain, juga dilaporkan mencapai $>22$. Kanibalisme yang terjadi pada perlakuan kontrol, memungkinkan FCR lobster pada perlakuan tersebut lebih rendah. Hal ini juga dapat dilihat pada SGR perlakuan kontrol yang lebih tinggi apabila dibandingkan dengan perlakuan SI. Pemanfaatan energi yang bukan berasal dari pakan, tetapi diperoleh dari hasil memangsa (kanibalisme), diduga menjadi sumber energi tambahan yang mendukung pertumbuhannya.

\section{Frekuensi Moulting}

Frekuensi moulting benih lobster pada penelitian ini berkisar antara $19 \pm 2,82-47,5 \pm 2,12$ kali selama masa pemeliharaan. Parameter frekuensi moulting juvenil lobster disajikan pada Gambar 6 .

Frekuensi moulting dapat dijadikan sebagai parameter pertumbuhan pada lobster. Pertumbuhan krustasea akan terjadi setelah adanya proses pergantian kulit (Fujaya et al., 2011). Hasil penelitian ini menunjukkan pemeliharaan lobster dengan perlakuan SI memiliki frekuensi moulting lebih tinggi dibandingkan perlakuan kontrol. Frekuensi moulting yang rendah pada kontrol disebabkan populasi lobster semakin berkurang hingga akhir pemeliharaan. Hal ini berkorelasi dengan nilai SR yang rendah pada perlakuan kontrol. Jumlah lobster yang terus berkurang, memengaruhi total jumlah karapas yang tanggal menjadi lebih sedikit.

\section{Sintasan}

Sintasan (SR) lobster tertinggi terdapat pada penggunaan $\mathrm{SI}$ - sebesar $92,85 \pm 2,02 \%$ sedangkan terendah terdapat pada kontrol sebesar 74,28 $\pm 4,04 \%$ Hasil analisis ragam menunjukkan, sintasan pada perlakuan kontrol berbeda nyata $(\mathrm{P}<0,05)$ dengan perlakuan selter individu.

Biomassa total lobster pada akhir pemeliharaan tertinggi terdapat pada, yaitu sebesar 2.128,75 \pm 46,31 g; sedangkan terendah terdapat pada perlakuan SI • sebesar 1.776,61 \pm 81,04\%. Penggunaan SI menghasilkan biomassa total yang berbeda nyata $(\mathrm{P}<0,05)$ dengan perlakuan $\mathrm{Sl} \bullet$, tetapi tidak berbeda nyata $(P>0,05)$ dengan kontrol dan SI $\Delta$. Secara keseluruhan, sintasan dan biomassa lobster akhir pada penelitian ini dapat dilihat pada Gambar 7 dan 8.

Pada kontrol, sintasan lobster adalah yang terendah. Hal ini disebabkan pada perlakuan kontrol masih memungkinkan terjadinya kontak antar lobster. Kontak antar lobster akan menyebabkan tingkat kanibalisme lobster menjadi tinggi, sehingga sintasan menjadi rendah. Hasil yang sama didapatkan oleh Irvin $\&$ Williams (2009), yang menemukan lobster Panulirus 


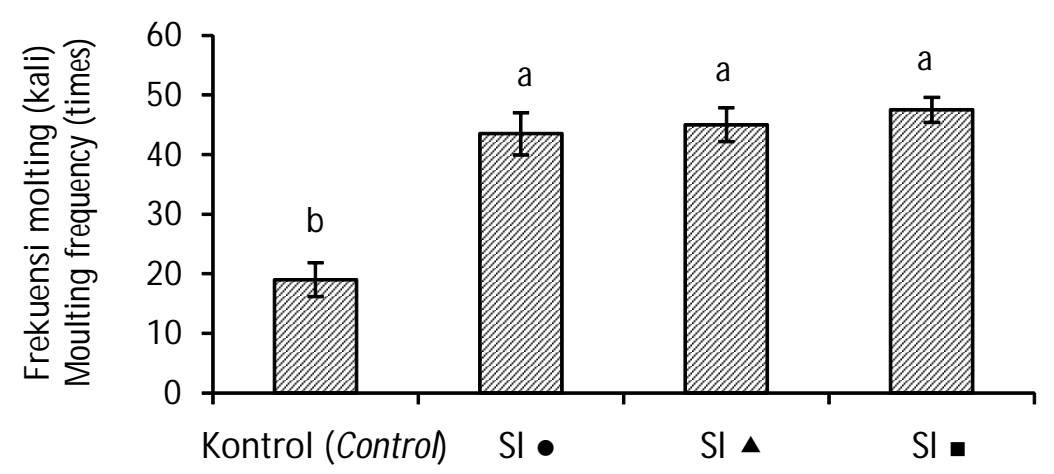

Gambar 6. Frekuensi moulting lobster selama pemeliharaan pada berbagai macam selter individu selama pemeliharaan. Huruf kecil yang berbeda dalam grafik menunjukkan beda nyata $(P<0,05)$.

Figure 6. Moulting frequency of lobsters during the study rearen in different individual shelter during the study. Different letters at the top of the bars indicate significantly different $(P<0.05)$.

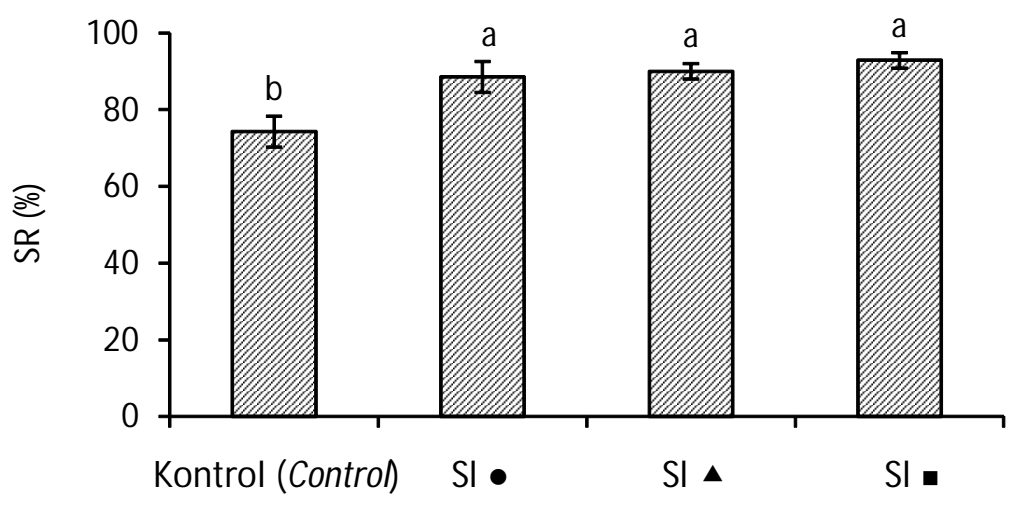

Gambar 7. Sintasan lobster pada akhir pemeliharaan. Huruf kecil yang berbeda dalam grafik menunjukkan beda nyata $(P<0,05)$.

Figure 7. Survival rate of lobsters at the end of the study. The different letters at the top of the bars indicate significantly different $(P<0.05)$.

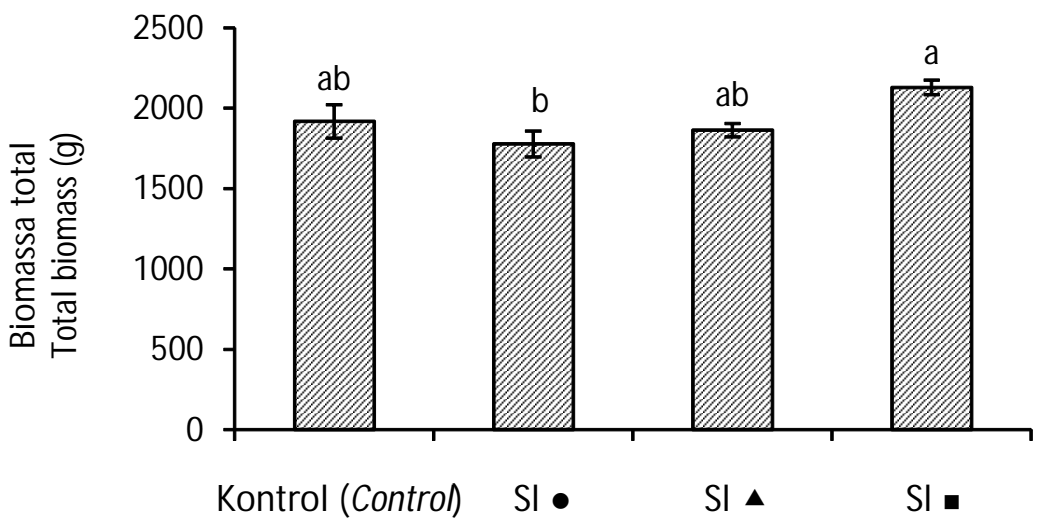

Gambar 8. Biomassa total lobster pada akhir pemeliharaan. Huruf kecil yang berbeda dalam grafik menunjukkan beda nyata $(P<0,05)$.

Figure 8. Lobsters total biomass at the end of the study. The different letters at the top of the bars indicate significantly different $(P<0.05)$. 
ornatus yang dipelihara menggunakan sistem individu mempunyai sintasan yang lebih tinggi yaitu sebesar $89 \%$ dibanding sistem komunal sebesar $72 \%$ Secara keseluruhan, penggunaan selter individu pada penelitian ini terbukti secara signifikan berpengaruh positif terhadap sintasan lobster yang dibudidayakan. Hal ini karena dengan penggunaan selter individu maka kontak antar lobster tidak ada, sehingga tidak ada faktor kanibalisme dalam wadah budidaya. SI . merupakan perlakuan yang terbaik untuk budidaya pendederan karena memiliki biomassa total lobster akhir tertinggi apabila dibandingkan dengan perlakuan lainnya.

\section{KESIMPULAN}

Berdasarkan hasil penelitian, penggunaan selter individu pada budidaya pendederan juvenil lobster pasir Panulirus homarus berpengaruh negatif terhadap respons pertumbuhan, tetapi memberi pengaruh positif terhadap sintasan juvenil lobster yang dibudidayakan. Secara keseluruhan, kondisi kualitas air menggunakan sistem resirkulasi masih memenuhi syarat untuk budidaya lobster. Penggunaan selter individu persegi direkomendasikan untuk tujuan pendederan karena menghasilkan total biomassa akhir tertinggi dibanding perlakuan lainnya.

\section{UCAPAN TERIMA KASIH}

Ucapan terima kasih disampaikan kepada Bapak Eddy Supriyono dan tenaga teknis (Tiwi, Iba, Eka, dan Habbie) yang telah membantu dalam kegiatan penelitian ini.

\section{DAFTARACUAN}

Bianchini, M.L. \& Ragonese, S. (2007). Growth of slipper lobsters of the Genus Scyllarides. In The biology and fisheries of the slipper lobster. Crustacean (Issues 17). Boca Raton, US: CRC Press, p. 215.

Biesterfeld, S., Farmer, G., Russell, P., \& Figueroa, L., (2003). Effect of alkalinity type andconcentration on nitrifying biofilm activity. Water Environment Research, 75, 196-204.

Budiardi, T., Widyaya, I., \& Wahjuningrum, D. (2007). Hubungan komunitas fitoplankton dengan produktivitas udang vaname Litopenaeus vannameidi Tambak Biocrete. Jurnal Akuakultur Indonesia, 6(2), 119-125.

Chen, S., Ling, J., \& Blancheton, J.P. (2006). Nitrification kinetics of biofilm as affected by water quality factors. Aquacultural Engineering, 34, 179-197.

Clesceri, L.S., Greenberg, A.E., \& Eaton, A.D. (1999). Standard methods for the examination of water and waste water. 20th ed. Washington DC, US: American Public Health Association.

Cokrowati, N., Utami, P., \& Sarifin. (2012). Perbedaan padat tebar terhadap tingkat pertumbuhan dan kelangsungan hidup post peurulus lobster pasir (Panulirus homarus) pada bak terkontrol. Jurnal Kelautan, 5(2), 156-166.

Drengstig, A., \& Bergheim, A. (2013). Commercial land-based farming of European lobster (Homarus gammarus L.) in recirculating aquaculture system (RAS) using a single cage approach. Aquacultural Engineering, 53, 14-18.

Fujaya, Y., Aslamyah, S., \& Usman, Z. (2011). Respons moulting, pertumbuhan, dan mortalitas kepiting bakau Scylla olivacea yang disuplementasi vitomolt melalui injeksi dan pakan buatan. Ilmu Kelautan, 16(4), 211-218.

Hargiyatno, I.T., Satria, F., Prasetyo, A.P., \& Fauzi, M. (2013). Hubungan panjang-berat dan faktor kondisi lobster pasir Panulirus homarus di perairan Yogyakarta dan Pacitan. Bawal, 5(1), 41-48.

Irvin, S.J. \& Williams, K.C. (2009). Comparison of the growth and survival of Panulirus ornatus seed lobsters held in individual or communal cages. ACIAR. Spiny Lobster Aquaculture in The Asia-Pacific Region, p. 89-95.

Lesmana, D. (2013). Evaluasi pemanfaatan kompartemen di keramba jaring apung terhadap tingkat stres dan pertumbuhan lobster pasir Panulirus homarus. Master's Tesis. Sekolah Pascasarjana Institut Pertanian Bogor. Bogor.

Mohammed, G., Syda-Rao, S., \& Ghosh, S. (2010). Aquaculture of spiny lobsters in sea cages in Gujarat, India. Journal of Marine Biological Assay, India, 52(2), 316-319.

Musbir, Sudirman, \& Palo, M. (2014). Penggunaan atraktor buatan yang ramah lingkungan dalam pemanenan anakan udang lobster laut Panulirus spp. Jurnal Ipteks PSP, 1(2), 95-102.

Nguyen, M.C., Nguyen, T.B.N., \& Le, T.N. (2009). Effect of different types of shelter on growth and survival of Panulirus ornatus juveniles. ACIAR. Spiny Lobster Aquaculture in The Asia-Pacific Region, p. 85-88.

Phillips, B.F. \& Kittaka, J. (2000). Spinny lobster: Fisheries and culture. Osney Mead (GB): Blackwell Science, p. 556-585.

Solanki, Y., Jetani, K.L., Khan, S.I., Kotiya, A.S., Makawana, N.P., \& Rather, M.A. (2012). Effect of stocking density on growth and survival rate of spiny lobster (Panulirus polyphagus) in cage culture system. International Journal of Aquatic Science, 3(1), 3-14. 
Suastika, M., Sukadi, F., \& Surahman, A. (2008). Studi kelayakan: Meningkatkan pembesaran dan nutrisi lobster di Nusa Tenggara Barat. In Jones, C (ed.). (23 pp) ACIAR-Smallholder Agribusiness Development Initiative (SADI) Report.

Syda-Rao, George, R.M., Anil, M.K., Saleela, K.N., Jasmine, S., Kingsly, H.J., \& Hanumanta, R.G. (2010). Cage culture of the spiny lobster Panulirus Homarus (Linnaeus) at Vizhinjam, Trivadrum along the South-West Coast of India. Indian Journal of Fisheries, 57(1), 23-29.
Thuy, N.T.B. \& Ngoc, N.B. (2004). Current status and exploitation of wild spiny lobsters in Vietnamese waters. Australian Canberra: Centre for International Agricultural, Proceedings of a workshop held at the Institute of Oceanography, Nha Trang, Vietnam, p. 13-16.

Wickins, J.F. \& Lee, D.O.C. (2002). Crustacean farming ranching and culture. London, UK: Blackwell Science Ltd.

Zonneveld, N.E., Huisman, A., \& Boon, J.H. 1991. Prinsip-prinsip budidaya ikan. Jakarta (ID): PT Gramedia Pustaka Utama, $285 \mathrm{hlm}$. 